\title{
KEDUDUKAN IZIN PRINSIP PENANAMAN MODAL ASING BADAN KOORDINASI PENANAMAN MODAL SEBAGAI DASAR PEMBUATAN AKTA PENDIRIAN PERSEROAN TERBATAS
}

\author{
Andi Kusuma Atmaja, Affifah Kusumadara, Siti Hamidah \\ Program Studi Magister Kenotariatan, Fakultas Hukum, Universitas Brawijaya \\ Jalan Abdul Muis 52-56A, Jakarta, 10160, \\ Email: andikusumaatmaja@gmail.com
}

\begin{abstract}
The purpose of writing this is: (1) analyze the application of principle permit foreign capital investment as a basis the ratification of establishment of the company limited enough to fulfill any legal certainty; (2) to provide knowledge mechanism permit application principle investment has been implemented proper and have met by the law.Methods used is juridical normative.First, principle permit investment is a the statute of the law or legal certainty should not based on a plan or description investors on which to base penerbitannya, because plan or description of investors or an applicant this can also not dilandaskan by honesty in terms of \& apos; re doing, by karennya the procedure or supporters that are be the basis of the issuance principle permit investment not be considered as evidence juridical strong and benefit the parties, the government agencies, and the community moreover principle permit investment this be the basis The legal entity limited liability. Both, refer Ease of Doing Business (EODB) done by world bank-international finance corporation (World Bank -IFC) that puts indonesia still bad at ease begin a venture or investing, it is suggested that principle license of the investment must be abolished that did not meet economic analysis of law that an outgrowth of the significance (utilitas) better than the value (Nilai); Utility (Kegunaan); and effeciency (efesiensi). For it, because there are still license more meet unsur-unsur of economic analysis of law or theory benefit .
\end{abstract}

Keywords: License of principle of foreign investment, Deed of establishment, Limited Liability Company

\begin{abstract}
Abstrak
Tujuan penulisan ini adalah: (1) menganalisis penerapan Izin Prinsip Penanaman Modal Asing sebagai dasar pengesahan Pendirian Perseroan Terbatas sudah memenuhi kepastian hukum; (2) Memberikan pengetahuan mekanisme permohonan Izin Prinsip Penanaman Modal telah dilaksanakan dengan tepat dan telah memenuhi ketentuan hukum. Metode yang digunakan adalah yuridis normatif. Pertama, Izin Prinsip Penanaman Modal merupakan suatu ketetapan hukum atau kepastian hukum seharusnya tidak dilandasi oleh suatu rencana atau keterangan penanam modal yang menjadi dasar untuk diterbitkan, karena rencana atau keterangan dari penanam modal atau pemohon ini bisa juga tidak dilandaskan oleh kejujuran dari segi penyampaiannya, oleh karennya landasan prosedur atau pendukung yang menjadi dasar penerbitan Izin Prinsip Penanaman Modal tidak dapat dikatakan sebagai bukti yuridis yang kuat dan mampu melindungi para pihak, pemerintah/lembaga, maupun masyarakat terlebih lagi Izin Prinsip Penanaman Modal ini menjadi landasan dari penerbitan pengesahan badan hukum Perseroan Terbatas. Kedua, merujuk Ease of Doing Bussiness (EODB) yang dilakukan oleh World Bank-International Finance Corporation (World Bank-IFC) yang menempatkan Indonesia masih buruk dalam kemudahan memulai usaha atau investasi, hal ini mengisyaratkan bahwa Izin Prinsip Penanaman Modal harus dihapuskan karena tidak memenuhi Economic Analysis of Law yang merupakan perkembangan dari teori kemanfaatan (utulitas) baik dari unsur Nilai (value); Kegunaan (utility); dan Efesiensi (Effecieny). Untuk itu, karena masih ada izin usaha yang lebih memenuhi unsur-unsur dari Economic Analysis of Law atau teori kemanfaatan.
\end{abstract}

Kata kunci: Izin prinsip penanaman modal asing, Akta pendirian, Perseroan Terbatas

\section{Pendahuluan}


Penanaman modal asing sebagai salah satu instrument ekonomi bagi masyarakat untuk kegiatan investasi. Sebagai instrument penanaman modal asing dapat berkembang dengan baik apabila dibangun berdasarkan prinsip wajar, transparan, dan aman. Prinsip tersebut ditujukan untuk melindungi kepentingan investor (investor protection) yang mampu melahirkan kepercayaan (trust) didalam mekanisme usaha. ${ }^{1}$

Peranan penanaman modal asing sebagai salah satu instrumen pembangunan ekonomi juga terefleksikan dalam tujuan yang tertera dalam Undang-undang Nomor 25 Tahun 2007 tentang Penanaman Modal Lembaran Negara Republik Indonesia Tahun 2007 Nomor 67 sebagai landasan hukum positif bagi kegiatan penanaman modal di Indonesia. Dalam UU Penanaman Modal tujuan penyelenggaraan penanaman modal disebutkan antara lain:

1. Meningkatkan pertumbuhan ekonomi Nasional;

2. Menciptakan lapangan pekerjaan;

3. Meningkatkan pembangunan ekonomi berkelanjutan;

4. Meningkatkan kemampuan daya saing usaha Nasional;

5. Meningkatkan kapasitas dan kemapuan teknologi Nasional;

6. Mendorong pengembangan ekonomi kerakyatan.

7. Mengelola ekonomi potensial menjadi kekuatan ekonomi riil dengan menggunakan dana yang berasal, baik dari dalam negeri maupun dari luar negeri.

8. Meningkatkan kesejahteraan masyarakat. ${ }^{2}$
Undang-undang Nomor 25 Tahun 2007 tentang Penanaman, Modal merupakan perangkat hukum terpenting dalam reformasi penanaman modal. Hal ini dapat dilihat dari hal yang mendasari lahirnya Undang-undang ini terpancar pada preambul Undang-undang tersebut sebagai berikut:

a. Bahwa dalam mewujudkan masyarakat yang adil dan makmur berlandaskan Pancasila dan Undang-undang Dasar Negara Republik IndonesiaTahun 1945 harus dilaksanakan dengan penyusunan ekomoni nasional yang berkelanjutan untuk mencapai tujuan Negara.

b. Bahwa Peraturan penanaman modal harus berdasarkan ekonomi kerakyatan yang mengikutsertakan perkembangan badanbadan usaha kecil dan menengah.

c. Bahwa untuk mencapai percepatan pembangunan ekonomi nasional dan mewujudkan kedaulatan politik Indonesia harus secara terus-menerus meningkatkan bidang penanaman modal dan pengelolaanpotensi ekonomi menjadi kekuatan ekonomi dengan menggunakan modal yang berasal dari dalam negeri ataupun dari luar negeri.

d. Bahwa keikutsertaan Indonesia dalamkerjasama Internsional dan perekonomian ekonomi global perlu untuk menciptakan iklim penanaman modal yang kondusif promotif dan berkepastian hukum adil dan effesien dengan tetap memperhatikan kepentingan ekonomi Nasional.

Didalam Preambul menimbang Peraturan Presiden Nomor 90 Tahun 2007 Tentang Peraturan Presiden Nomor 90 Tahun 2007 Tentang - 
Peraturan-peraturan mengenai Badan Koordinasi Penanaman Modal Perlu penyesuaian karena tidak sesuai dengan pembangunan hukum nasional kebutuhan dan percepatan perkembangan khusus dibidang penanaman modal sebagaimana dijelaskan dalam sebagai berikut:

a. Bahwa dalam rangka meningkatkan efektivitas dan efesiensi pelaksanaan tugas badan Koordinasi Penanaman Modal untuk menciptakan iklim investasi yang kondusif perlu dilakukan reorganisasi dan revitalisasi organisasi Badan Koordinasi Penanman Modal dengan Peraturan Presiden.

b. Bahwa sehubungan dengan hal tersebut pada huruf $a$, dipandang perlu untuk mengatur kembali Badan Koordinasi Penanaman Modal.

Patut untuk pahami apa itu Penanaman Modal menurut pasal 1 ayat (1) UU Penanaman Modal adalah: "Penanaman Modal adalah segala bentuk kegiatan penanaman modal, baik oleh penanam modal dalam negeri maupun penananam modal asing untuk melakukan usaha di wilayah Negara Republik Indonesia." Sedangkan penanaman modal asing menurut Pasal 1 ayat (6) Peraturan Kepala Badan Penamaman Modal Nomor 6 tahun 2016 tentang Perubahan Atas Peraturan Kepala Badan Pedoman Penanaman Modal mensyaratkan, bagi Koordinasi Penanam Modal Nomor 14 Tahun 2015 Tentang Pedoman Dan Tata Cara Izin Prinsip Penanaman Modal (selanjutnya disebut "PP BKPM Nomor 6 Tahun 2016") adalah: "Penanaman Modal Asing, yang selanjutnya disebut PMA adalah kegiatan menanam modal untuk melakukan usaha di wilayah Negara Republik Indonesia yang dilakukan oleh Penanam Modal
Asing, baik yang menggunakan modal asing sepenuhnya maupun yang berpatungan dengan penanaman modal dalam negeri."

Peran penting dari penanaman modal asing bagi ekonomi dan kehidupan masyarakat tidak sejalan baik dengan kondisi pelayanan permohonan perizinan penanaman modal khusus penanaman modal asing ini yang diantaranya ketidakpastian waktu, data-data dan dokumen-dokumen yuridis dalam prosedur pemberian perizinan yang disampaikan, oleh karenannya analisis SWOT (Strengths, Weaknesses, Opportunities, Theats) sangat penting untuk melakukan analisis yang cermat tentang faktor-faktor yang berhubungan dengan lingkugan internal terhadap berbagai hal yang menyangkut perizinan saat ini. Kemudian melakukan identifikasi sebagai faktor secara sistematis untuk merumuskan strategi pemerintah berikut analisis SWOT yang digambarkan dalam table sebagai berikut: ${ }^{3}$

\section{SWOT Analisis Perizinan}

1) Peluang

a. Dalam era terbuka perluang untuk berinovasi menyederhanakan prosedur perizinan untuk memancing minat dalam dunia usaha investasi.

b. Membuka peluang kesempatan kerja.

c. Meningkatkan PAD.

2) Kekuatan

a. Memiliki dasar hukum yang jelas.

b. Bertujuan untuk melaksanakan ketertiban baik tertib lingkungan sesuai dengan RT/RW.

c. Bertujuan menambah PAD.

3) Kelemahan

5 Adrian Sutendi, Hukum Perizinan, Jakarta: Sinar Grafika, 2011, hlm 22. 
a. Dasar hukum tidak kuat dan bertentangan dengan peraturan lain (tumpang tindih) dan juga terjadi duplikasi persyaratan.

b. Mekanisme berbelit-belit membutuhkan waktu yang relative panjang.

4) Ancaman

a. Lingkungan hidup dapat rusak dan tidak sesuai dengan RT/RW jika lingkungan diabaikan hanya untuk mengejar PAD.

b. Peluang dunia usaha dan tenaga kerja akan berkurang apabila prosedur perizinan terlalu sulit untuk dilaksanakan.

c. PAD akan berkurang dengan berkurangnya investor atau rendahnya minat untuk berusaha.

Berdasarkan ketentuan Pasal 1 ayat (16)

Peraturan Kepala Badan Koordinasi Penanaman Modal Nomor 13 Tahun 2017 tentang Pedoman dan Tata Cara Perizinan dan Fasilitas Penanaman Modal menerangkan bahwa: "Pendaftaran Penanaman Modal adalah bentuk persetujuan pemerintah yang merupakan izin prinsip sebagai dasar penerbiatan Perizinan dan Pemberian Fasilitas pelaksanaan Penanaman Modal."

Saat ini kinerja pelayanan publik sebagai aparat pemerintah sampai dengan saat masyarakat menilai belum maksimal, begitu pula dalam hal pelayanan publik penanaman modal asing. Hal ini membuat target peningkatan ekonomi dari sektor penanaman modal asing masih belum maksimal. Setidaknya ada tiga masalah utama yang dihadapi oleh aparatur pemerintah sebagai pelaksanan pelayanan publik yakni sebagai berikut:

1. Rendahnya kualitas pelayanan publik yang dilaksanakan oleh sebagian aparatur pemerintahan dan administrasi Negara. Kondisi ini karena didalam kerangka hukum administrasi positif Indonesia saat ini telah diatur tentang standart minimum pelayanan, namun kepatuhan terhadap standar minimum pelayanan publik masih belum termanifestasikan dalam pelaksanaan tugas aparatur Pemerintahan.

2. Birokasi yang panjang (red-tape bureauacracy) dan adanya tumpang tindih tugas dan kewenangan, yang menyebabkan penyelenggaraan pelayanan publik menjadi panjang dan melalui proses yang berbelit-belit, sehingga besar kemungkinan timbul ekonomi biaya tinggi, terjadinya penyalahgunaan wewenang, korupsi, kolusi dan nepotisme, perlakuan diskriminatif, dan sebagainya.

3. Rendahnya pengawasan ekternal dari masyaratkat (social control) terhadap penyelenggarahan pelayanan publik, sebagai akibat ketidakjelasan standar prosedur penyampian keluhan pengguna jasa pelayanan publik. Oleh itu, tidak cukup dirasakan adanya tekanan sosial (social pressure) yang memaksa penyelenggara pelayanan publik harus memperbaiki kinerja mereka. ${ }^{4}$

Pemerintah dalam hal ini berperan penting dalam kemudahan berinvestasi di Negara Indonesia diantaranya adalah melakukan penyederhanaan pelaksanaan perizinan yang professional, bermanfaat, effektif, value dan tidak tumpang tindih. untuk itu Pemerintah harus lebih merancang sektor pelayanan publik untuk mendorong pencapian investasi di indoensia untuk menjadi lebih baik dan maju. Pada saat ini Pemerintah sedang mewajibkan

6 Adrian Sutendi, Ibid, hlm 24 
Kementerian, Badan dan Lembaga-lembaga Negara untuk memgutamakan kemudahan investasi dan usaha yang dituangkan didalam Peraturan Presiden Nomor 91 Tahun 2017 Tentang Percapatan Pelaksanaan Berusaha yang menjadi dasar tujuan Peraturan Presiden ini dapat dilihat dari preambul menimbang pada Peraturan Presiden ini sebagai berikut:

d. Bahwa Perkembangan jumlah, penyebaran, skala, maupun efesiensi kegiatan usaha merupakan penentu utama pertumbuhan ekonomi, penciptaan lapangan kerja, pengurangan kemiskinan serta ketimpangan antara daerah maupun kelompok pendapatan;

e. Bahwa perizinan berusaha yang diterbitkan oleh Kementerian/ Lembaga dan Pemerintah daerah untuk memulai, melaksanakan, dan mengembangkan kegiatan usaha, perlu ditata kembali agar menjadi pendukung dan bukan sebaliknya menjadi hambatan perkambangan kegiatan usaha;

f. Bahwa penataan kembali sebagaimana dimaksud dalam huruf $b$, diwujudkan dalam bentuk huruf $b$, diwujudkan dalam bentuk pelayanan, pengawalan (end to end), dan peran aktif penyelesaian hambatan pelaksanaan berusaha melalui pembentukan Satuan Tugas pada tingkat nasioal, kementerian/ lembaga, daerah propinsi, dan daerah kabupaten kota;

g. Bahwa dalam rangka percepatan pelaksanaan berusaha di kawasan ekonomi khusus. Kawasan perdagangan bebas dan pelabuhan bebas, kawan industry, dan/atau kawasan pariwisata sudah dapat dilaksanakan dalam bentuk pemenuhan persayaratan (checklist);

Bahwa untuk penyerdehanaan lebih lanjut perlu diatur dan ditetapkan kembali standart pelayanan kementerian/ lembaga, daerah propinsi, dan daerah kabupaten/ kota, melalui reformasi peraturan yang diperlukan untuk melaksanakan kegiatan usaha;

h. Bahwa untuk mempercepat dan mempermudah pelayanan untuk berusaha perlu menerapkan pengunaan teknologi informasi melalui Sistem Perizinan berusaha Terintegrasi Secara Elektronik (Online Single Submission);

i. Bahwa berdasarkan pertimbangan sebagaimana dimaksud dalam huruf $a$, huruf $b$, huruf $c$, huruf $d$, huruf $c$ dan huruf $f$, perlu menetapkan Peraturan Presiden tentang Percepatan Pelaksanaan Berusaha.

j. Dampak dari Peraturan Presiden ini sudah banyak izin yang dikaji yang akan dihapuskan seperti Izin Ganguan (HO), Izin Tempat Usaha, Izin Prinsip Bagi Usaha Menengah dan Kecil, Izin Amdal dan Kepala Badan Koordinasi Penanaman Modal (BKPM) Fanky Sibarani mengukakan, akan ada beberapa perizinan yang dihilangkan dan kemudian disatukan berkaitan dengan harmonisasi izin seperti izin mendirikan bangunan, izin lingkungan dan izin ganguan. "Tujuannya, sebetulnya ini bukan penyederhanaan, melainkan Presiden geram kepada banyaknya perizinan. Satu izin yang terkait dengan ease of doing business, terkait dengan daya saing, izinnya itu" ${ }^{7}$ 
Sebelumnya hal serupa juga telah dikemukakan dalam Undang-Undang Nomor 25 Tahun 2009 Tentang Pelayanan Publik yang perlu didalam Pasal 1 ayat (7) Undang-undang ini menjelaskan bentuk pelayanan publik yaitu: "Standar pelayanan adalah tolak ukur yang dipergunakan sebagai pedoman penyelenggaraan pelayanan dan acuan penilaian kualitas pelayanan sebagai kewajiban dan janji penyelenggaran kepada masyarakat dalam rangka pelayanan yang berkualitas, cepat, mudah, terjangkau dan terukur."

Oleh karenya perlu untuk menyederhanakan kembali perizinan terkait investasi agar mampu memberikan manfaat bagi perekenomian di Indoensia. Hukum positif yang melandasi penyelenggaran investasi pada Badan Koordinasi Penanaman Modal sebagaimana dimaksud dalam UU Penanaman Modal sudah baik, namun perlu dilakukan penyederhanaan. Penyederhanaan ini juga tergambar pada asas penyelenggaraan penanaman modal sebagaimana dimaksud didalam Pasal 3 ayat (1) UU Penanaman modal sebagai berikut: "Penanaman modal diselenggarakan berdasarkan asas: (1) Kepastian hukum; (2) Keterbukaan; (3) Akuntabilitas; (4) Perlakuan yang sama dan tidak membedakan asal Negara; (5) Kebersamaan; (6) Efesiensi berkeadilan; (7) Berkelanjutan; (8) Berwawasan lingkungan; (9) Kemandirian; dan (10) Keseimbangan kemajuan dan kesatuan ekonomi."

Namun dalam hal sebagaimana dimaksud dalam Pasal 3 tersebut di atas guna menciptakan iklim investasi yang kondusif diperlukan dilakukan perubahan penegakan hukum (law enforcement) ada tiga unsur yang harus diperhatikan antara lain:
(1) kepastian hukum (rectssicherheit atau legal certainty); (2) kemanfaatan (zweckmassigkeit atau benefit); dan (3) keadilan (gerechtigkeit atau justice). Dimana ketiga unsur tersebut di atas harus berjalan dengan sinergi dan harmonis sehingga terjadi keseimbangan hukum. Apabila penegakan hukum hanya memperhatikan kepastian hukum semata, maka pelaksanaannya dapat mengabaikan keadilan serta kemanfaatan dimasyarakan, begitu pula sebaliknya apabila salah satu unsur tersebut terlalu diutamakan, maka pelaksanaanya dapat mengabaikan unsur-unsur lainnya. ${ }^{8}$ Yang dapat membuat ketidakseimbangan hukum dalam pelaksananya.

Pelaksanaan penanaman modal asing di Indonesia diantaranya dilakukan oleh badan hukum berbentuk Perseroan Terbatas sebagaimana dinyatkan dalam Pasal 5 ayat (2) UU Penanaman Modal yaitu: "Penanaman modal asing wajib dalam bentuk Perseroan Terbatas berdasarkan hukum Indonesia dan berkedudukan di dalam wilayah indonesia, kecuali ditentukan lain oleh undangundang".

Sebelum mendirikan suatu badan hukum Perseroan Terbatas penanam modal asing terlebih dahulu melakukan permohonan Izin Prinsip Penanaman Modal sebagaimana dimaksud dalam Pasal 1 ayat (9) PP BKPM Nomor 6 Tahun 2016 adalah: "Segala bentuk persetujuan untuk melakukan penanaman modal yang dikeluarkan oleh Pemerintah Pusat, Pemerintah Daerah, Badan Pengusahaan Kawasan Perdagangan Bebas dan Pelabuhan Bebas, dan Administrator Kawasan Ekonomi Khusus, yang memiliki kewenangan sesuai dengan ketentuan Perundang-undangan."

8 David Kairupan.Op.,Cit, hlm 4 
Izin Prinsip Penanaman Modal ini wajib dimiliki terlebih dahulu oleh Perseroan Terbatas dengan fasilitas penanaman modal baik dalam negeri maupun asing, sebagaimana dimaksud dalam Pasal 1 ayat (10) dalam PP BKPM Nomor 6 tahun 2016 Izin Prinsip Penanaman Modal Asing pada Badan Koordinasi Penanaman Modal Asing sebagai berikut:

"Izin Prinsip Penanaman Modal, yang selanjutnya disebut izin prinsip, adalah izin yang wajib dimiliki dalam rangka memulai usaha."

khusus untuk Izin prisip penanaman modal asing dilakukan oleh Pemerintah Pusat yang dalam hal ini diberikan kewenangan kepada Pelayanan Terpadu Satu Pintu (“PTSP”) Pada Badan Koordinasi Penanaman Modal ("BKPM") sebagaimana dinyatakan didalam pasal 5 ayat (1) PP BKPM Nomor 6 Tahun 2016 didalam PP BKPM dimaksud dalam Pasal 5 ayat (2) huruf (a), (b), (c) sebagai berikut:

"Penanaman Modal Asing dan Penanaman Modal menggunakan Nomor 6 Tahun 2016 ini juga menerangkan perihal bentuk dari Penanaman Modal Asing sebagaimana modal asing, sebagaimana dimaksud pada ayat 1 huruf (b) angka (5) meliputi: (a) Penanaman Modal Asing yang dilakukan oleh pemerintah Negara lain; (b) Penanaman Modal Asing yang dilakukan oleh warga negara asing atau badan usaha asing; (c) Penanam Modal yang menggunakan modal asing yang berasal dari pemerintah Negara lain. Yang didasarkan pada perjanjian yang dibuat oleh pemerintah dan pemerintah Negara lain."
Dapat dilihat bahwa Badan Koordinasi Penanaman Modal memberikan proses bahwa dalam mendapatkan izin prinsip penanaman modal, penanam modal diberikan 2 (dua) mekanisme antara lain:

Tahap Pertama:

1. Penanam modal melakukan permohonan izin prinsip penanaman modal di PTSP Badan Koordinasi Penanaman Modal;

2. Pemesanan nama perseroan;

3. Membuat Akta Pendirian Perseroan Terbatas di hadapan Notaris;

4. Melakukan Permohonan Surat Keterangan Domisili Perusahaan (SKDP);

5. Melakukan Permohonan Nomor Pokok Wajib Pajak (NPWP)

6. Melakukan permohonan Surat Pengesahan Badan Hukum pada kementerian

Tahap Kedua:

1. Pemesanan nama Badan Hukum Perseroan Terbatas;

2. Membuat Akta Pendirian Perseroan Terbatas di hadapan Notaris;

3. Melakukan Permohonan Surat Keterangan Domisili Perusahaan (SKDP);

4. Melakukan Permohonan Nomor Pokok Wajib Pajak (NPWP)

5. Penanam modal melakukan permohonan izin prinsip penanaman modal di PTSP Badan Koordinasi Penanaman Modal;

6. Melakukan permohonan Surat Pengesahan Badan Hukum pada kementerian.

Pada tabel atas menjelaskan bahwa Izin Prinsip Penanaman Modal yang harus dimiliki Penanaman modal sebelum dan sesudah - 
penanam modal melakukan kegiatan usaha Indonesia yang prosedurnya dilandasakan oleh suatu rencana atau keterangan penanam modal dalam menjalankan kegiatan usahanya di wilayah Indonesia. ${ }^{10}$

Dari keterangan-keterangan itu yang bukan merupakan tidak dilandaskan dari bukti hukum yang dapat dibukti membuat prosedur Penanaman Modal Asing ini perlu dilakukan kajian apakah penerapan tidak bertentangan atau berbenturan dengan ketentuan-ketentuan hukum lain yang berkaitan dan berlaku serta memberikan manfaat, sehingga Izin Prinsip Penanaman Modal ini dapat memberikan kepastian hukum, perlindungan hukum dan efektif bagi sistem investasi di Indonesia. Sebenarnya pemerintah telah melakukan berbagai rencana aksi untuk meningkatkan iklim usaha namun belum terjadi perbaikan peningkatan kemudahan berusaha di Indonesia yang signifikan. Survey Ease of Doing Bussiness (EODB) 2015 yang dilakukan World Bank-International Finance Corporation (World Bank -IFC) masih menempatkan Indonesia pada peringkat 144, meskipun terlah terjadi perbaikan 3 (tiga) peringkat tersebut dibanding tahun sebelumnya namun peringkat tersebut masih tergolong buruk. Peringkat tersebut menempatkan Indonesia jauh dibawah negara-negara tetangga seperti Malaysia, Filipina bahkan rata-rata kemudahan berusaha di kawasan Asia Timur dan Pasifik. Selanjutnya peringkat Indonesia dalam hal kemudahan memulai usaha (starting a business) jauh lebih buruk yaitu peringkat 155 pada tahun $2015 .{ }^{11}$
Untuk itu evaluasi terhadap Penerbitan Izin Prinsip terlebih sangat penting dilakukan oleh pemerintah. Terlebih lagi diberikan pada saat status badan hukum Perseroan Terbatas belum mendapatkan pengesahan oleh Kementerian Hukum dan Hak Asasi Manusia sehingga dapat dikatakan diberikan kepada Subjek Hukum fiktif atau belum ada/ lahir. dalam Pasal 12 ayat 2 Peraturan Kepala Badan Koordinasi Penanaman Modal Nomor 6 Tahun 2016 tentang Perubahan atas Peraturan Kepala Badan Koordinasi Penanaman Modal Nomor 14 Tahun 2015 Tentang Pedoman dan Tata Cara Izin Prinsip Penanaman Modal menjelaskan bahwa:

"Izin Prinsip dalam rangka PMA diberikan dalam rangka pembentukan PT di Indonesia atau sudah berbadan hukum Indonesia dan berkedudukan didalam wilayah Negara Republik Indonesia, kecuali ditentukan lain oleh Undang-undang."

Sedangkan Perseroan Terbatas menurut Undang-undang Nomor 40 Tahun 2007 tentang Perseroan Terbatas Pasal 1 ayat (1) menjelaskan Perseroan Terbatas adalah: "Perseroan Terbatas, yang selanjutnya disebut Perseroan, adalah badan hukum yang merupakan persekutuan modal. Didirikan berdasarkan Perjanjian, melakukan kegiatan usaha dengan modal dasar yang seluruhnya terbagi atas saham dan memenuhi persyaratan yang ditetapkan dalam Undang-undang ini serta peraturan pelaksanaanya."

Dan untuk mendapatkan status entitas sebagai suatu badan hukum Perjanjian yang buat para pihak tersebut menjadi Anggaran Dasar bagi perseroan Terbatas yang selanjutnya menjadi -

10 Pasal 1 ayat 10 tentang Perubahan Atas Peraturan Kepala Badan Pedoman Penanaman Modal mensyaratkan, bagi Koordinasi Penanam Modal Nomor 14 Tahun 2015 Tentang Pedoman Dan Tata Cara Izin Prinsip Penanaman Modal

11 www.bkpm.go.id/images/uploads/ppid/file_upload/Rencana_Strategis_\%28RENSTRA\%29_BKPM_TA_2015_-_2019.pdf, terakhir diakses pada tanggal 11 Juli 2018. 
acuan. Anggaran Dasar ini perlu mendapatkan pengesahan dari Pemerintah yang dalam hal ini didelegasikan kepada Kementerian Hukum Dan Hak Asasi Manusia yang menurut Pasal 7 ayat 4 Undangundang Nomor 40 Tahun 2007 tentang Perseroan Terbatas menyatakan yaitu bahwa: "Perseroan Terbatas memperoleh status badan hukum pada tanggal diterbitkanya Keputusan Menteri mengenai Pengesahan Badan Hukum Perseroan Terbatas."

Dari perjelasan tersebut menjelaskan bahwa pemberian Izin Prinsip Penanaman Modal oleh Badan Koordinasi Penanaman Modal ini telah mengesampingkan ketentuan dan peraturan hukum lainnya, selain itu juga pada Pasal 1 ayat (20) Peraturan Kepala Badan Koordinasi Penanaman Modal Nomor 6 Tahun 2016 tentang Perubahan atas Peraturan Kepala Badan Koordinasi Penanaman Modal Nomor 14 Tahun 2015 Tentang Pedoman dan Tata Cara Izin Prinsip Penanaman Modal menjelaskan tentang pimpingan perusahan/ perseroan terbatas sebagai berikut: "Pimpinan Perusahaan adalah direksi/pimpinan perusahaan yang tercantum dalam anggaran dasarl akta pendirian perusahaan atau perubahannya yang telah mendapatkan pengesahan/persetujuan/ pemberitahuan dari Menteri Hukum dan Hak Asasi Manusia (Menteri Hukum dan HAM) bagi badan hukum perseroan terbatas dan sesuai dengan peraturan perundang-undangan untuk selain badan hukum perseroan terbatas."

Dilihat dari pasal ini menjelaskan untuk melakukan permohonan dan penandatangan adalah seorang perwakilan dari Direksi yang namanya tercatat dan tertuang didalam anggaran Dasar Perseroan Termasuk dengan Surat Pengesahan/ Persetujuan/
Pemberitahuan/ Pelaporan. Hal ini tidak selaras atau bersinergi dengan lampiran dan penjelasan pengisian pada formulir permohonan izin prisnsip penanaman modal dalam Peraturan Kepala Badan Koordinasi Penanaman Modal Republik Indonesia Nomor 6 Tahun 2016 tentang Perubahan atas Peraturan Kepala Badan Koordinasi Penanaman Modal Nomor 14 Tahun 2015 tentang Pedoman dan Tata Cara Izin Prinsip Penanaman Modal yang menjelaskan perihal Nama Perusahaan dalam Formulir adalah: "Merupakan identitas perusahaan. Bagi perusahaan yang belum berbadan hukum Indonesia nama perusahaan akan tercatum nama tentatif yang merupakan nama sementara sebelum disahkan oleh Menteri Hukum dan HAM, jika dalam pelaksanaan nama perusahaan tidak disetujui oleh Menteri Hukum dan HAM, maka perusahaan dapat mengajukan perubahan nama perusahaan."

Dari hal ini menandakan adanya kekaburan hukum dalam menjelakan tentang anggota yang sah menurut ketentuan hukum adalah Direksi yang namanya tertuang dan ternyata dalam Anggaran Dasar Perseroan Terbatas yang seharusnya tindakan sah mewakili Perseroan apabila dan telah mendapatkan pengesahan/ persetujuan/ pemberitahuan dari Menteri Hukum dan Hak Asasi Manusia yang berhak mengajukan permohonan izin penanaman modal pada Badan Koordinasi Penanaman Modal. Tapi didalam pelaksanaanya khusus untuk Pendirian Perseroan Terbatas Penanaman Modal Asing baru, penanaman modal diwajibkan untuk melampirkan dan mengisi permohonan dan melampiran data-data/ dokumendokumen dan diakses pada Sistem.

12 http://www.hukumonline.com/berita/baca/t56e909ee2201c/pemerintah-hilangkan-izin-gangguan-izin-tempat-usaha-dan-izinprinsip-ukm, terakhir diakses pada tanggal 12 Juli 2018. 
Pelayanan Informasi dan Perizinan Investasi Secara Elektronik (SPIPISE). Dan sebagaimana dimaksud dalam Lampiran Peraturan Badan Koordinsi Penanaman Modal Republik Indonesia Nomor 13 Tahun 2017 Tentang Pedoman dan Tata Cara Perizinan dan Fasilitas Penanaman Modal yang terlampir dalam tesis ini diantaranya penanam modal baru wajib:

1. Melampirkan Perjanjian Kerjasama dengan orang atau badan hukum Indonesia tentang badan hukum yang akan didirikan;

2. Melampirkan rekanaman Perjanjian Sewa Ruang Kantor;

3. Komposisi modal Perseroan terbatas yang akan didirikan.

Hal ini dapat menimbulkan konflik dan permasalahan dari kewajiban data-data/ dokumendokumen di atas. Dan bagaimana perlindungan para pihak pemodal dalam negeri dalam rangka kerjasama patungan (joint venture) dengan penanaman modal asing apabila terjadi banyak ketidakpuasan antara kedua belah pihak. Untuk itu Pemerintah sangat diperlukan melalui suatu kebijakan yang terarah dan dapat memberikan kepastian hukum serta keadilan diantara kedua belah pihak. Tidak dapat dipungkiri bahwa dengan adanya kerjasama Penanam Modal Asing dengan dalam Negeri akan melahirkan berbagai implikasi dan salah satunya adalah terjadinya sengketa yang harus diselesaikan secara tuntas agar tidak menimbulkan dampak yang buruk dimata penanam modal asing begitu juga sebaliknya. ${ }^{12}$

Sehingga terkait dengan pemberian izin prinsip penanaman modal terhadap badan hukum Perseroan Terbatas yang belum mendapatkan pengesahan badan hukum secara konstitusi belum disahkan atau diakui sebagai suatu badan hukum akan menimbulkan dampak negative dikemudia hari nanti hal ini perlu di antisipasi oleh Pemerintah khususnya Badan Koordinasi Penanaman Modal itu sendiri. Sehingga apabila dilihat dari manfaat penerbitan izin prinsip penanaman modal ini kurang memberikan manfaat dan menjamin kepastian hukum. Terlebih lagi penanaman modal apabila telah meralisasikan rencana investasi yang tertuang dalam Izin Prinsip Penanaman Modal juga diwajibkan untuk membuat Izin Usaha yang menurut Pasal 1 ayat (14) Peraturan Badan Koordinsi Penanaman Modal Republik Indonesia Nomor 13 Tahun 2017 Tentang Pedoman dan Tata Cara Perizinan dan Fasilitas Penanaman Modal sebagai berikut: "Izin usaha adalah izin yang wajib dimiliki perusahaan untuk memulai pelaksanaan kegiatan produksi/ operasi yang menghasilkan barang atau jasa, kecuali ditentukan lain oleh peraturan perundang-undangan."

Hal ini membuatkan bagi penanam modal dan membuat prosedur pengajuan izin pada Badan Kordinasi Penanaman Modal kurang mempunyai manfaat yang mampu menghabat pertumbuhan investasi dan peningkatan EODB Investasi di Indonesia yang diharapkan oleh Pemerintah sebagaimana diisyaratkan dalam Peraturan Presiden Republik Indonesia Nomor 91 tahun 2017 tentang Percepatan Pelaksanaan Berusaha. Dalam pasal 2 ayat (1) Peraturan Presiden Republik Indonesia Nomor 91 tahun 2017 tentang Percepatan Pelaksanaan Berusaha menyatakan sebagai berikut oleh dikarenakan hal itu Penulis tertarik untuk melakukan penelitian lebih lanjut -

13 Amiuddin IImar, Hukum Penanaman Modal Di Indonesia, Jakarta:Kencana, 2017, hlm 72 
dengan judul: "Kedudukan Izin Prinsip Penanaman Modal Asing Badan Koordinasi Penanaman Modal (BKPM) Sebagai Dasar Pembuatan Akta Pendirian Perseroan Terbatas."

Pada tulisan ini terdapat isu-isu hukum yang perlu dibahas diantaranya sebagai berikut: (1) Apakah regulasi tentang penerbitan Izin Prinsip Penanaman Modal Asing atas Pendirian Perseroan Terbatas telah sesuai dengan Asas Kemanfaatan/Utilitas?; (2) Bagaimana prosedur pemberian Izin Prinsip Penanaman Modal yang menjadi dasar atas Pengesahaan Badan Hukum Perseroan Terbatas mempunyai nilai kemanfaatan?

Metode yang digunakan adalah hukum yuridis normatif yaitu suatu pengertian hukum yang meletakkan hukum sebagai sistem norma. Sistem norma yang dimaksud adalah mengenai asas-asas, norma-norma, kaidah dari peraturan perundangundangan, putusan pengadilan, perjanjian serta doktrin (ajaran). ${ }^{13}$ Tipe penelitian hukum yang dilakukan dengan pertimbangan bahwa titik tolak penelitian analisis terhadap peraturan Perundangundangan yang membuka peluang terjadinya praktik ${ }^{14}$ yang dalam penulisan ini merujuk kepada peraturan Perundang-undangan tentang Izin Prinsip Penanaman Modal dan kewenangan Badan Koordinasi Penanaman Modal Asing dan Perseroan Terbatas.

\section{Pembahasan}

Sesuai dengan kajian yang telah dijelakan dalam BAB 1 mengenai Izin Prinsip Penanaman Modal sebagai instrument masalah serta menyatakan hal ini Sedangkan izin (vergunning) adalah suatu persetujuan dari penguasa berdasarkan Undang-undang atau Peraturan pemerintah untuk dalam keadaan tertentu menyimpang dari ketentuan-ketentuan larangan peraturan perundang-undangan. Izin dapat juga diartikan sebagai dispensasi atau pelepasan/ pembebasan dari suatu larangan. ${ }^{15}$

Pelaksanaan perizinan pada teori Negara hukum modern ("Negara hukum yang demokratis") adalah campuran antara konsep Negara hukum ("rechtsstaats") dengan konsep Negara kesejahteraan ("welfare state"). Negara hukum secara merupakan Negara yang menempatkan hukum sebagai tumpuan tertinggi didalam penyelenggaraan, bernegara atau pemerintahan. Negara hukum adalah negara menjadikan hukum sebagai patokan tertinggi didalam penyelenggaraan kenegaraan atau pemerintahan, maka didalam Negara hukum wajib untuk selalu mematuhi norma hukum, untuk menjamindan melindungi hak-hak bangsa dalam dibidangsipil politik sosial ekonomi atau budaya. Sehingga hukum merupakanlandasan terpenting dalam penyelengaraan kenegaraan dan pemerintahanuntuk mencapai masyarakat yang damai adil dan sejahtera. Kegiatan kenegaraan atau pemerintahan harus melihat bentuk penyelenggaraan kepentingan masyarakat (public, service), dimana hak-hak masyarakat mesti dilayani dan dilindungi. ${ }^{16}$

Oleh itu Izin Prinsip Penanaman Modal harus memenuhi segala persyaratan sama dengan izin lainnya, menurut Soehino, syarat-syarat dalam izin itu bersifat konstitutif dan kondisional. Bersifat konstitutif, karena ditentukan suatu perbuatan atau tingkah laku tertentu yang harus dipenuhi terlebih

\footnotetext{
14 Salim HS dan Erlies Setianan Nurbani, Penerapan Teori Hukum Pada Penelitian Tesis dan Desertasi, Depok, PT. Rajagrafindo Persada, 2013, hlm 13

15 Jhonny Ibrahim, Teori dan Metodologi Penelitian Hukum Normatif, Malang, Bayumedia Publishing, 2008, hal 57

16 Ibid, hal.167

17 Ibid, hlm 3
} 
dahulu. Artinya dalam pemberian perizinan itu ditentukan suatu perbuatan konkret, dan bila tidak dipenuhi dapat dikenakan sanksi. Bersifat kondisional, karena penilaian tersebut baru ada dan dapat dilihat serta dapat dinilai setalah perbuatan dan tingkah laku yang disyaratkan itu terjadi. Penentuan pesyaratan dan prosedur perizinan ini dilakukan secara sepihak oleh pemerintah. Meskipun demikian, pemerintah tidak boleh membuat atau menentukan prsedur dan persyaratan menurut kehendaknya sendiri secara arbitrer (sewenang-wenang), tetapi harus sejalan dengan peraturan perundang-undangan yang menjadi dasar dari perizinan tersebut. Dengan kata lain, ${ }^{17}$ Badan Koordinasi Penanaman Modal tidak boleh menentukan syarat melampaui batas tujuan yang hendak dicapai oleh peraturan hukum yang menjadi dasar perizinan.

Dalam regulasi dan deregulasi, persyaratan dalam proses perizinan menjadi satu yang paling utama, arah perbaikan sistem perizinan kedepan, paling tidak memunuhi kreteria sebagai berikut:

1. Tertulis dengan jelas, yaitu regulasi sulit telaksana dengan baik tanpa tertulis dengan jelas oleh karena itu, regulasi perizinan pun harus dituliskan dengan jelas.

2. Memungkinkan untuk dipenuhi, yaitu perizinan harus berorientasikan pada kemudahan untuk dilaksanakan oleh pengurus izin. Meskipun tetap memperhatikan sasaran regulasi yang bersifat ideal.

3. Berlaku universal, yaitu perizinan hendaknya tidak menimbulkan efek diskriminatif. Perizinan harus bersifat inklusif dan universal.
4. Memiliki spesifikasi, yaitu perizinan harus memperhatikan spesifikasi teknis dan aspek lainnya yang terikat (termasuk memenuhi ketentuan Internasional). ${ }^{18}$

\subsection{Konsep Dasar Perizinan Terhadap Izin Prinsip Penaman Modal Asing}

Perizinan adalah salah satu bentuk pelaksanaan fungsi pengaturan dan bersifat pengendalian yang dimiliki oleh Pemerintah terhadap kegiatan-kegiatan yang dilakukan oleh masyarakat. Perizinan dalam rangka penanaman modal adalah segala bentuk persetujuan untuk melakukan penanaman modal yang dikeluarkan oleh pemerintah dan pemerintah daerah yang memiliki kewenangan sesuai dengan ketentuan peraturan. Dalam rangka peningkatan pelayanan terhadap para investor, BKPM (Badan Koordinasi Penanaman Modal) antara lain telah memprakarsai pelaksanaan PTSP (Pelayanan Terpadu Satu Pintu). Dalam pelaksanaan system PTSPbertujuan untuk menciptakan penyederhanaan untuk menciptakan penyederhanaan dan percpatan penyelesaian perizinan.

Dalam pengaturan perizinan investasi di Indonesiaini ditemukan proses atau prosedur perizinan berbelit-belit dan berlapis, sehingga terkesan tidak menjamin kepastian hukum, efektif dan efisien. Walaupun beberapa instansi sudah memperkenalkan system pelayan perizinan yang mutakhir oleh unit pelayanan satu atap. ${ }^{19} \mathrm{Hal}$ ini dapat dilihat dari Pasal 17 Peraturan Kepala Badan Nomor 13 Tahun 2017 Koordinasi Penanaman Modal tentang Pedoman dan Tata

18 Ridwan H.R., Hukum Administrasi Negara, Jakarta Rajagrafindo, 2006, hlm 217.

19 Andrian Sutendi, Op., Cit., hal 184

20 file://ID:/BAHAN\%20KULIAH\%20PASCA\%20UB\%20SMTR\%201/TESIS/Peraturan\%20Penanaman\%20Modal/JURNAL\%20MAS ALAH\%20BKPM.pdf, terakhir diakses pada tanggal 10 Juli 2018. 
Cara Perizinan dan Fasilitas Penanaman Modal yang menyatakan bahwa: "Permohonan Pendaftaran Penanaman Modal untuk PMDN dan PMA diajukan sebelum dan sesudah perusahaan berbadan usaha atau berbadan hukum Indonesia."

Dikarenakan Izin Prinsip Penanaman Modal Asing merupakan suatu izin yang dapat menjadi bukti dari suatu ketetapan pemerintah atas suatu hal yang dilarang, maka sebaiknya penerbitan Izin Prinsip Penanaman Modal Asing ini diberikan sesudah berbadan hukum yaitu pada saat telah mendapatkan Pengesahan sebagai Badan Hukum oleh Kementerian Hukum dan Has Asasi Manusia sebagaimana dinyatakan dalam Pasal 7 ayat (4) Nomor 40 Tahun 2017 tentang Undang-undang Perseroan Terbatas. Dan dalam prosedur pemberiannya juga mensyaratkan persyaratan yang berbelit-beli dan berlapis hal ini terlihat didalam Lampiran I Peraturan Badan Koordinasi Penanaman Modal Republik Indonesia Tahun 13 Tahun 2017 tentang Pedoman dan Tata Cara Perizinan dan Fasilitas Penanaman Modal sebagaimana terlampir dalam penulisan tesis ini.

Selain itu juga Izin Prinsip Penanaman Modal merupakan izin rujukan bagi izin lainya sebagaimana dimaksud dalam Pasal 10 ayat (3) Peraturan Kepala Badan Kordinasi Penanaman Modal Nomor 14 Tahun 2015 tentang Pedoman dan Tata Cara Izin Prinsip Penanaman Modal sebagai berikut: "Izin Prinsip sebagaimana dimaksud dalam pada ayat (1) merupakan rujukan bagi perizinan dan non perizinan pelaksanaan penanaman modal baik yang menjadi kewenangan pemerintah dan kewenangan daerah."
Hal ini menyatakan bahwa Izin Prinsip Penanaman Modal merupakan suatu ketetapan yang memiliki landasan yuridis yang kuat atau kekuatan yuridis. Oleh karenya dasar pengajuannya pun harus dilakukan oleh landasan hukum yang jelas dan dapat dibuktikan. Pemberian izin prinsip penanaman modal asing sebelum suatu badan hukum Perseroan Terbatas mendapatkan pengesahan diselenggarakan dengan nilai (value) baik dari segi hukum ataupun ekonomi yang diantaranya untuk memberikan kepastian hukum dan kemudahan bagi para investor untuk berinvestasi di Indonesia, sehingga mampu untuk meningkatkan perekonomian Indonesia, mengurangi tinggat pengguran dan menimbulkan kepercayaan serta kebahagian kepada masyarakat sehingga dampak dari suatu peningkatan investasi sehingga mempunyai nilai kegunaan baik bagi penanam modal asing maupaun lokal untuk melakukan kegiatan usahanya, masyarakat maupun pemerintah.

Belum lagi dengan kewajiban penanam modal yang telah mendapatkan Izin Prinsip Penanaman Modal Asing untuk segera mengajukan Izin Usaha Perdagangan, Jasa atau industri, dalam jangka waktu yang tertera pada Izin Prinsip Penanaman Modal yang diterbitkan Badan Koordinasi Penanaman Modal sebagaimana dimaksud dalam pasal 22 ayat (1) sebagai berikut: "Masa berlaku pendaftaran Penanaman Modal sama dengan Jangka Waktu Penyelesaian Proyek yang ditetapkan dalam pendafataran Penanaman Modal. Setelah batas waktu yang penanam modal asing dan untuk memulai kegiatan produksi maka, 
penanam modal harus segera mengajukan Izin Usaha hal ini berdasarkan Pasal 1 ayat 17 menjelaskan bahwa: "Izin usaha adalah izin yang wajib dimiliki perusahaan untuk memulai produksi/ operasi, kecuali ditentukan lain oleh peraturan perundang-undangan." Dengan ketentuan dan tata cara izin usaha sebagaimana dijelaskan dalam Pasal 24 ayat (2) Peraturan sebagai berikut: "Perusahaan yang memiliki pendafataran penanaman modal/ izin prinsip/ izin investasi yang masih berlaku dan akan melakukan kegiatan produksi/ operasi wajib memiliki izin usaha sesuai dengan ketentuan peraturan perundang-undangan sektor usaha."

Di dalam Pasal 17 Peraturan Kepala Badan Koordinasi Penanaman Modal tentang Pedoman dan Tata Cara Perizinan dan Fasilitas Penanaman Modal sebagaimana telah dijelaskan di atas bahwa pemberian Izin Prinsip Penanaman Modal dapat diajukan sebelum dan sesudah perusahaan berbadan usaha atau berbadan hukum. Hal ini perlu pemahaman tentang Perseroan Terbatas yang segala ketentuan dan aturan dalam pelaksanaan wajib dimuat didalam Anggaran Dasar yang merupakan suatu Perjanjian pendirinya atau para pemegang saham sebagai bentuk kepastian hukum dari tindakan dan merupakan Undang-undang bagi pembuatnya sebagaimana dimaksud dalam Pasal 1338 KUHPerdata. Peningkatan invetasiberdampak juga kepada pejabat umum Notaris ("openbaar ambtenaar'), yang bertujuan memberikan kepastian hukum para pihak atas perbuatan hukum yang dilakukannya. Notaris dalam hal kegiatan penanaman modal khususnya pada Penanaman Modal Asing adalah membuat akta pendirian serta membantu pengesahan status badan hukum. Dan tidak menutup kemungkinan untuk melakukan pengurusan izin prinsip serta perizinan lainnya yang telah menjadi kebiasaandengan tujuan untuk mencipatakan ketertiban dan perlindungan hukum yang berintikan kebenaran dan keadilanbagi para pihak. ${ }^{20}$

Akta Pendirian dan Pengesahan Badan Hukum Perseroan Terbatas merupakan kesatuan dan bagian yang tidak dapat terpisahkan atas pemberian status badan hukum Indonesia yang merupakan instrument hukum terpenting dalam melakukan kegiatan penanaman modal di Indonesia. Akta pendirian Perseroan Terbatas yang dibuat dihadapan Notaris merupakan akta otentik seperti dijelakan didalam pasal 1868 KUHPerdata dimana "suatu akta otentik ialah suatu akta yang dibuat dalam bentuk yang ditentukan Undangundang oleh atau di hadapan pejabat umum yang berwenang untuk itu ditempat akta itu." Dan juga dijelaskan pada Pasal 165: HIR sebagai berikut: "akta otentik yaitu suatu akta yang dibuat oleh atau dihadapan pejabat yang diberi wewenang untuk itu, merupakan bukti yang lengkap antara para pihak dan para ahli warisnya dan mereka yang mendapat hak daripadanya tentang yang tercantum di dalamnya dan bahkan tentang yang tercantum didalamnya sebagai pemberitahua belaka." Junto Pasal 285 Rbg. ${ }^{21}$ Akta Pendirian Perseroan terbatas ini menjadi patokan para pendiri atau parapemegang saham dalam menjalankan tindakan hukum selama Perusahaan, guna memberi kepastian hukum.

Di dalam penanaman modal asing izin

21 https://ejournal.unsrat.ac.id/index.php/lexprivatum/article/download/6167/5693, terakhirdiakses pada tanggal 25 Oktober 2017.

22 Adrian Sutedi, Op., Cit, hlm 3 
prinsip penanam modal menjadi landasan utama dalam pengesahan statusbadan hukum perseroan terbatas, menurut Pasal 1 ayat (10) Peraturan Kepala Badan Koordinasi Penanaman Modal Nomor 25 Tahun 2007 mewajibkan bagi para investor terlebih dahulu melakukan permohonan izin prinsip penanaman modal baik itu sebelum atau sesudah membuat Pendirian Perseroan Terbatas, hal ini bertentangan dengan ketentuan yang diatur didalam pasal 7 ayat (4) Undang-Undang Nomor 40 tahun 2007 tentang Perseroan Terbatas. ${ }^{22}$

Izin Prinsip Penanaman Modal yang diterbitkan baik sebelum atau sesudah pengesahan Pendirian Badan Hukum Perseroan Terbatas adalah tidak tepat karena Izin Prinsip Penanaman diberikan kepada badan hukum yang secara lahiriah belum ada atau belum berdiri/ disahkan, karena yang menjadi dasar utama lahirnya suatu badan hukum adalah pengesahaan yang merupakan amanat kontitusi untuk Perseroan Terbatas sebagai subjek hukum.didalam staablad 1864 tentang preneving dimana adanya setiap recht person (Badan Hukum) baru wajib untuk diberikan pengesahan oleh Negara.

Dapat dipahami bahwa atas dasar uraian di atas, maka dapat disimpulkan bahwa izin usaha yang menjadi dasar utama bagi penanam modal untuk memulai, melakukan serta merealisasikan kegiatan usahal produksi, sehingga dapat disimpulkan penerbitan Izin Prinsip Penanaman Modal tidak terlalu efesien yang dalam kamus bahasa indonesia berarti ketepatan cara (usaha kerja) dalam menjalankan sesuatu (dengan tidak membuang waktu) atau kemampuan menjalankan tugas dengan baik dan tepat (dengan tidak membuang waktu, tenaga, biaya), dan juga di dalam prosedurnya permohoanan Izin Prinsip Penanaman Modal ini berdasarkan uraian diatas tidak menjamin kepastian hukum karena bertentangan dengan peraturan perundang-undangan lain. Oleh karenaya Izin Prinsip Penanaman Modal tindak hanya memperhatikan dari asas kepastian hukum namun juga harus memenuhi asas kemanfaatan/ utilitas dan asa keadilan sehingga terjadi keseimbangan hukum.

\subsection{Implikasi Peraturan Presiden Nomor 91} Tahun 2017 Tentang Percepatan Pelaksanaan Berusaha Terhadap Izin Prinsip Penanaman Modal.

Kepala Pemerintahan atau Presiden sudah sangat geram terhadap pelayanan perzinan ini, yang terlalu berbelit-berlit dan berlarut-larut sehingga Presiden megeluarkan instruksi dengan menerbitkan Peraturan Nomor 91 Tahun 2017 tentang Percepatan Pelaksanaan Berusaha, dengan membentuk Satuan Tugas untuk menyelesaikan hambatan dan penyerderhanaan perizinan sebagaimana dijelaskan pada Pasal 1 ayat 1 Peraturan Presiden tersebut:"Satuan Tugas adalah satuan tugas yang dibentuk untuk meningkatkan pelayanan, pengawalan, peyelesaian, hambatan, penyerderhanaan, dan pengembangan sistem online dalam rangka percepatan pelaksanaan perizinan berusaha termasuk bagi udaha mikro, kecil, dan menengah setelah mendapatkan persetujuan penanaman modal."

Sedangkan yang dimaksud Perizinan -

23 Pasal 7 ayat (4) UUPT 40 Th. 2007 "Perseroan terbatas memperoleh status badan hukum yaitu pada saat tanggal Keputusan Menteri mengenai Pengesahan badan hukum" 
Berusaha pada Pasal 1 ayat 2 Peraturan Presiden ini adalah: "Perizinan berusaha adalah persetujuan yang diperlukan Pelaku Usaha untuk memulai dan menjalankan usaha dan diberikan dalam bentuk Persetujuan yang dituangkan dalam bentuk surat/ keputusan atau pemenuhan persyaratan (checklist)."

Di dalam Peraturan Presiden ini pada Pasal 2 menjelaskan perihal percepatan pelaksanaan berusaha terdiri dari 2 tahap yaitu:

a. Tahap Kesatu, yaitu:

1. Pengawalan dan penyelesaian hambatan melalui pembentukan satuan tugas ;

2. Pelaksanaan perizinan berusaha dalam bentuk pemenuhan persyaratan (checklist) yang dilakukan di KEK, KPBPB, Kawasan Industri dan KSPN; dan

3. Pelaksanaan perizinan berusaha dengan menggunakan data sharing dan penyampaian yang tidak berulang yang dilakukan diluar KEK, KPBPB, Kawasan Industri, dan KSPN.

b. Tahap Kedua, yaitu:

1. Pelaksaan reformasi peraturan perizinan berusaha; dan

2. Penerapan sistem perizinan berusaha terintegrasi secara elektronik (online single submission).

Badan Koordinasi Penanaman Modal didalam peraturan Presiden yaitu sebagai Anggota dari satuan tugas nasional menurut Pasal 4 ayat 2 , hal ini mengambarkan bahwa Badan Koordinasi Penanaman Modal wajib turut serta untuk melakukan penyerhanaan dan menyelesaikan permasalahan-permasalahan perizinan berusaha.

Hal ini dapat dilihat dari Huruf 1 Peraturan Presiden tersebut di atas perihal percepatan pelaksanaan berusaha tersebut yang menjelaskan bahwa Menteri/ kepala lembaga, gubernur, dan bupati/ walikota melakukan evaluasi atas seluruh dasar hukum pelaksanaan proses perizinan berusaha yang merupakan kewenangan, termasuk bagi usaha mikro, kecil dadn menengah. ${ }^{23}$ Evaluasi yang dimaksud di atas mencangkup pula rekomendasi penyempurnaan atas peraturan perundang-undangan yang menjadi referensi atau dasar hukum penerbitan perizinan berusaha yang dilaksanakan oleh satuan tugas nasional, satuan tugas kementerian/ lembaga, satuan propinsi dan/ atau satuan tugas kabupaten/ kota. ${ }^{24}$

Setelah dilakukan evaluasi, maka kepada Menteril kepala lembaga, dan pejabat-pejabat daerah baik itu pada tingkat 1 atau tingkat 2 dapat menganti peraturan hukum yan menjadi dasar hukum pelaksanaan perizinan berusaha sebelumnya. ${ }^{25}$ Sehingga dari ketentuan-ketentuan pada Peraturan Presiden ini sebagai landasan Badan Koordinasi Penanaman Modal untuk terus melakukan penyederhanan Perizinan yang merupakan dari tanggung-jawabnya.

Oleh karenya Badan Kooordinasi Penanaman Modal wajib untuk melakukan evaluasi terhadap bentuk dan urgensi Izin Prinsip Penanaman Modal untuk itu perlu untuk diketahui konsep bagaimana bentuk dan urgensi dari suatu Izin. Bentuk yang dikeluarkan pemerintah dalam -

\footnotetext{
24 Pasal 28 ayat (1), Peraturan Presiden Nomor 91 tahun 2017 tentang Percepatan Pelaksanaan Berusaha

25 Pasal 28 ayat (2), Peraturan Presiden Nomor 91 tahun 2017 tentang Percepatan Pelaksanaan Berusaha

26 Pasal 28 ayat (3), Peraturan Presiden Nomor 91 tahun 2017 tentang Percepatan Pelaksanaan Berusaha
} 
hal ini Badan Koordinasi Penanaman Modal dapat dibedakan dari sisi wujudnya yang terbagi menjadi 2 hal, yaitu keputusan lisan dan keputusan tertulis. Pertama, keputusan lisan dikeluarkan pemerintah terhdap hal yang bersifat mendesak atau segera harus diambil. Kiranya tidak terlalu sulit untuk mendapatkan gambaran mengenai hal ini, seperti dalam hal terjadinya peristiwa force majeure (kejadian diluar batas kemampuan manusia) keputusan yang harus diambil dikarenakan tidak ada waktu yang cukup untuk menyusun keputusan tertulis.

Kedua, keputusantertulis yang mana keputusan ini lazim digunakan oleh pemerintah dan pada umumnya dibuat melalui serangkaian proses dalam jangka waktu tertentu, sekalipun masa berlakunya tidak lama. Untuk dapat diterbitkan sebuah izin perlu proses dan prosedur tertentu yang kadang kala tidak singkat. Diawali pengajuan permohonan oleh pihak yang mempunyai kepentingan untuk melakukan kegiatan usaha, sebagai instrument untuk menjamin kepastiaan dapat disebutkan beberapa urgensi dari izin, misalnya sebagai landasan hukum, sebagai instrument untuk melindungi kepentingan, dan sebagai alat bukti. ${ }^{26}$

1) Izin Sebagai Landasan Hukum

Izin sebagai landasan hukum dapat dipahami bahwa kegiatan tertentu memang tidak dapat dilakukan oleh warga masyarakat tanda adanya izin dari organ pemerintahan yang berwenang. Kenyataan tersebut dapat dimengerti karena izin menjadi dasar hukum bagi pelaku pelaku usaha untuk memulai kegiatan usaha. ${ }^{27}$ Dari hal ini sebenarnya Izin Usaha yang menpunyai landasan hukum bukan Izin Prinsip Penanaman Modal yang merupakan rencana investasi penanam modal. Izin Usaha adalah izin yang diberikan kepada penanam modal untuk memulai dan merealisasikan usaha bagi penanam modal sebagaimana dimaksud dalam Pasal 11 ayat 1 Peraturan Kepala Badan Koordinasi Penanaman Modal tentang Pedoman dan Tata Cara Perizinan dan Fasilitas Penanaman Modal sebagai berikut: "untuk memulai Produksi/ Operasi, baik untuk PMDN maupun PMA, wajib memilik Izin Usaha”.

2) Izin Sebagai Instrumen Menjamin Kepastian Hukum.

Didalam izin pada umumnya dimuat berbagai hal, baik yang bersifat maupun objektif. Misalnya izin itu siapa yang diberikan hak untuk dapat melakukan kegiatan usaha yang identitasnya dicantumkan dengan jelas pada suatu izin yang didalamnya terdapat batasan, baik mengenai waktu, lokasi, volume maupun hal-hal deskriptif lain yang menyangkut sesuatu yang bersifat objektif. Dengan muatan yang demikian izin tentu digunakan sebagai pegangan oleh pemegang izin untuk memberikan kepastian kegiatan apa yang diberikan, disetujui atau diizinkan dan sebagainya. ${ }^{28}$

Dari hal ini apabila dikaitkan dengan Izin Prinsip Penanaman Modal yang mauatanya adalah rencana dari penanam modal untuk melakukan kegiatan usahanya tidak memenuhi instrument menjamin kepastian hukum. Oleh -

27 Y. Sri Pudyatmoko, Op., Cit, hlm 22

28 Ibid, hlm 22

29 Ibid, hlm 23 
karenya Izin Prinsip Penanaman Modal ini seharusnya dihapuskan atau digantikan dengan suatu ketetapan atau informasi yang kekuatan hukumnya lebih rendah daripada izin. Sehingga apabila Izin Prinsip Penanaman Modal ini di hapuskan atau digantikan dengan ketetapan di bawah izin akan memberikan manfaat dan meningkatkan percepatan usaha dalam hal investasi.

3) Izin Sebagai Instrumen Untuk Melindungi Kepentingan.

Izin sebagai sebuah keputusan dapat digunakan untuk menjadi instrument perlindungan kepentingan, baik itu kepentingan permohoan, pemerintah, maupun kepentingan lainnya. Dapat dimengerti bahwa izin dapat digunakan untuk melindungi kepentingan pemegang Izin. Karena untuk melakukan kegiatan tertentu sering kali tidak lepas dari kewajiban pemenuhan persyaratan yang didalamnya termasuk serangkaian pengujian. Apabila pemohon kemudian diberikan izin, maka di dalamnya terkandung makna bahwa kegiatan itu telah teruji sehingga baik, aman, dan sebagainya. Izin juga merupakan perlindungan kepentingan pemerintah karena dalam izin sering kali ada beberapa klausula yang memungkinkan pemerintah untuk mengambil tindakan apabila izin itu dilanggar. Dalam hal tertentu, izin juga mempunyai manfaat bagi perlindungan kepentingan masyarakat sebagai pihak ketiga. ${ }^{29}$

Izin Prinsip Penanaman Modal dari instrument ini yang merupakan keterkaitan dari instrument lainya memperkuat bahwa Izin Prinsip
Penanaman Modal ini seharusnya dihapuskan atau digantikan dengan ketetapan lain yang kekuatannya di bawah izin sebagai suatu ketetapan yang harus mempunyai kepastian hukum, nilai, kegunaan dan efesiensi, karena didalam proses prosedur permohonannya muatan izin prinsip adalah sebuat rencana atau wacana dari para pihak permohonya sebelum direalisasikan menjadi Izin Usaha.

Sehingga Izin Prinsip Penanaman Modal ini tidak melindungi kepentingan dari pemegang izin baik itu penanam modal asing atau penanam modal lokal, pemerintah maupun masyarakat. Jika dibandingkan dengan proses pengesahan Badan Hukum Perseroan Terbatas saat ini Notaris menjadi perpanjangan Kementerian Hukum dan Hak Asasi Manusia untuk melakukan pembuatan akta pendirian, akses pengesahan/ persetujuan/ pelaporan/ pemberitahuan tetang Perseroan Terbatas yang atas hal tersebut juga Notaris diberikan kewenangan untuk segara menerbitkan dan memberikan pengesahan/ persetujuan/ pelaporan/ pemberitauan Perseroan Terbatas tentang Perseroan Terbatas sehingga terjadi ketetapan waktu, kemudahan usaha dan kemanfaat baik dari segi ekonomi.

Seharusnya hal ini diperhatikan bahwa untuk dapat dilakukan juga oleh Badan Kordinasi Penanaman Modal asing dalam menerbitkan Izin Prinsip Penamanan Modal dengan mamemanfatkan perangkat-perangkat hukum yang saling berkaitan untuk membantu pecepatan berusaha dan penigkatan investasi di Indonesia, serta mendongkrak peringkat indonesia pada Ease of Doing Bussiness sehingga pelayanan berusaha di Negara Indonesia tidak lagi tergolong sebagai - 
yang terburuk.

\section{Kesimpulan}

1. Izin Prinsip Penanaman Modal yang merupakan suatu ketetapan hukum atau kepastian hukum seharusnya muatannya tidak dilandasi oleh suatu rencana atau keterangan penanam modal yang menjadi dasar penerbitanya karena rencana atau keterangan dari penanam modal atau pemohon ini bisa tidak diladaskan oleh kejujaran dari segi penyampaianya, oleh karenya landasan atau pendukung atau dasar yang menjadi penerbitan Izin Prinsip Penanaman Modal tidak dapat dikatakan sebagai bukti yuridis yang kuat sehingga mampu melindungi para pihak, pemerintah/ lembaga, maupun masyarakat terlebih lagi Izin Prinsip Penanaman Modal ini menjadi landasan dari penerbitan pengesahan badan hukum Peseroan Terbatas.

2. Merujuk Ease of Doing Bussiness (EODB) yang dilakukan oleh World BankInternational Finance Corporation (World Bank -IFC) yang menepatkan indonesia masih buruk dalam kemudahan memulai usaha atau investasi mengisyaratkan bahwa Izin Prinsip Penanaman Modal ini tidak memenuhi unsur Economic Analysis of Law yang merupakan perkembangan dari teori kemanfaatan (utulitas) bagi dari unsur Nilai (value); Keguanaan (utility); dan Efesiensi (Effecieny). Sehingga sebaiknya dihapuskan karena akan masih ada izin usaha yang lebih memenuhi unsur-unsur dari Economic Analysis of Law atau teori kemanfaatan.

\section{DAFTAR PUSTAKA}

\section{Buku}

H.R, Ridwan. Hukum Administrasi Negara. Jakarta: Rajagrafindo, 2006.

HS, Salim dan Erlies Setianan Nurbani. Penerapan Teori Hukum Pada Penelitian Tesis dan Desertasi . Depok: Rajagrafindo Persada, 2013.

Ibrah, Jhonny. Teori dan Metodologi Penelitian Hukum Normatif. Malang: Bayumedia Publishing, 2008.

Ilmar, Amiuddin. Hukum Penanaman Modal Di Indonesia. Jakarta: Kencana, 2017.
Kairupan, David. Aspek Hukum Penanaman Modal Asing Indonesia. Jakarta: Kencana Prenadamedia Group, 2013.

Sutendi, Adrian. Hukum Perizinan. Jakarta: Sinar Grafika, 2011.

\section{Jurnal Dan Artikle}

Indra safitri, Jurnal legalisasi Indonesia"Iklim Penanaman Modal Indonesia", Jakarta: Direktorat Jendral Peraturan Perundangundangan Departemen Hukum dan Hak Asasi Manusia Republik Indonesia, 2008. 
Internet

http://www.hukumonline.com/berita/baca/t56e909e e2201c/pemerintah-hilangkan-izingangguan-izin-tempat-usaha-dan-izinprinsip-ukm, terakhir diakses pada tanggal 12 Juli 2018.

www.bkpm.go.id/images/uploads/ppid/file_upload/R encana_Strategis_\%28RENSTRA\%29_BK PM_TA_2015_-_2019.pdf, terakhir diakses pada tanggal 11 Juli 2018

file://ID:/BAHAN\%20KULIAH\%20PASCA $\% 20$ UB $\% 2$ OSMTR $\% 201 /$ TESIS/Peraturan\%20Penan aman\%20Modal/JURNAL\%20MASALAH\% 20BKPM.pdf, terakhir diakses pada tanggal 10 Juli 2018.

https://ejournal.unsrat.ac.id/index.php/lexprivatum/a rticle/download/6167/5693, terakhirdiakses pada tanggal 25 Oktober 2017

\section{Peraturan Perundang-undangan}

Undang-Undang Nomor 40 Tahun 2007 tentang Perseroan Terbatas Lembaran Negara Republik Indonesia Tahun 2007 Nomor 106.

Undang-Undang Nomor 25 Tahun 2007 tentang Penanaman Modal Lembaran Negara Republik Indonesia Tahun 2007 Nomor 67.

Peraturan Kepala Badan Penamaman Modal Nomor 6 tahun 2016 tentang Perubahan Atas Peraturan Kepala Badan Pedoman Penanaman Modal mensyaratkan, bagi Koordinasi Penanam Modal Nomor 14 Tahun 2015 Tentang Pedoman Dan Tata
Cara Izin Prinsip Penanaman Modal, Berita Negara Tahun 2016 Nomor 853

Peraturan Presiden Republik Indonesia Nomor 90 tahun 2007 Tentang Badan Koordinasi Penanaman Modal, dimuat dalam Berita Negara Nomor 1483 tahun 2015.

Peraturan Presiden Nomor 39 tahun 2014 tentang Daftar Bidang Usaha Yang Tertutup Dan Bidang Usaha Yang Terbuka Dengan Persyaratan Di Bidang Penanaman Modal, Lemabaran Negara Republik Indonesia Tahun 2014 Nomor 93

Peraturan Menteri Hukum dan Hak Asasi Manusia Repubik Indonesia Nomor 1 tahun 2016 tentang Perubahan Atas Peraturan Menteri Hukum Dan Hak Asasi Manusia Nomor 4 Tahun 2014 Tentang Tata Cara Pengajuan Permohoan Pengesahan Badan Hukum Dan Persetujuan Perubahan Anggaran Dasar Serta Penyampaian Pemberitahuan Perubahan Anggaran Dasar dan PErubahan Data Perseroan, Berita Negara Republik Indonesia Tahun 2016 Nomor 113

Peraturan Presiden Nomor 91 tahun 2017 tentang Percepatan Pelaksanaan Berusaha, Lembaran Negara Republik Indonesia Tahun 2017 Nomor 210

Peraturan Badan Koordinasi Penanaman Modal Republik Indonesia Nomor 13 Tahun 2017 tentang Pedoman dan Tata Cara Perizinan dan Fasilitas Penanaman Modal, dimuat dalam Berita Negara Republik Indonesia tahun 2017 Nomor 1767. 